\title{
Analisis Pengaruh Perencanaan Audit dan Kompetensi Auditor Pada Kualitas Audit di Perwakilan BPKP Provinsi Bali
}

\author{
Ahmad Fajrin Azizi ${ }^{1}$ \\ Ketut Muliartha ${ }^{2}$ \\ ${ }^{1}$ Fakultas Ekonomi dan Bisnis Universitas Udayana (Unud), Bali, Indonesia \\ email: ahmadfajrinazizi@gmail.com/ Telp: 085648355987 \\ ${ }^{2}$ Fakultas Ekonomi dan Bisnis Universitas Udayana (Unud), Bali, Indonesia
}

\begin{abstract}
ABSTRAK
Perencanaan audit dan kompetensi auditor dibutuhkan untuk melakukan audit judgement dimana ketepatan judgement yang dihasilkan oleh auditor dalam menyelesaikan pekerjaan audit memberikan pengaruh pada kesimpulan akhir. Tujuan penielitian ini adalah untuk menganalisis pengaruh perencanaan audit dan kompetensi auditor pada kualitas audit di Perwakilan Badan Pengawasan Keuangan dan Pembangunan (BPKP) Provinsi Bali. Penelitian ini dilakukan di Kantor Perwakilan BPKP Provinsi Bali. Jumlah sampel yang diambil sebanyak 77 Pejabat Fungsional Auditor (PFA), dengan metode purposive sampling dengan syarat PFA yang memiliki sertifikasi auditor dan tidak sedang melaksanakan pendidikan di luar bali selama pengambilan sampel. Pengumpulan data dilakukan melalui teknik kuesioner. Teknik analisis yang digunakan adalah regresi linier berganda dengan menggunakan SPSS. Hasil analisis menunjukkan bahwa terdapat pengaruh positif dan signifikan antara perencanaan audit dan kompetensi auditorpada kualitas audit.
\end{abstract}

Kata kunci: Perencanaan audit, kompetensi auditor, kualitas audit

\begin{abstract}
Audit planning and auditor competence are needed to conduct audit judgments where the accuracy of judgment produced by the auditor in completing the audit work has an influence on the final conclusion. The purpose of this study was to analyze the influence of audit planning and auditor competency on audit quality at the Representative of the Bali Provincial Finance and Development Supervisory Agency (BPKP). This research was conducted at the Bali Provincial BPKP Representative Office. The number of samples taken were 77 Auditor Functional Officers (PFA), with purposive sampling method with PFA requirements that had auditor certification and were not carrying out education outside Bali during sampling. Data collection is done through questionnaire techniques. The analysis technique used is multiple linear regression using SPSS. The results of the analysis show that there is a positive and significant influence between audit planning and auditor competence on audit quality.
\end{abstract}

Keywords: audit planning, auditor competence, audit quality

\section{PENDAHULUAN}

Pengawasan oleh Aparat Pengawas Intern Pemerintah (APIP) memegang peranan penting untuk memberikan keyakinan bahwa penyelenggaraan pemerintah dan pertanggungjawaban melalui sistem akuntabilitas tersebut dapat dilaksanakan 
seperti yang diharapkan. APIP untuk dapat melaksanakan pengawasan intern pemerintah tersebut harus didukung dengan sumber daya manusia yang memiliki kemampuan untuk merencanakan pengawasan dan kompetensi yang memadai. Salah satu kegiatan utama yang dilakukan oleh APIP adalah audit (PERMENPAN, 2007).

Menurut Goverment Accountability Office (GAO) mendefinisikan kualitas audit sebagai ketaatan terhadap standar dan ikatan kontrak selama melaksanakan audit (Lawensohn, et al: 2007). Kualitas audit juga merupakan pelaporan tentang kelemahan pengendalian intern dan kepatuhan terhadap peraturan dan perundangundangan yang berlaku.

Auditor dalam melaksanakan audit harus memiliki keahlian/kompetesi. Standar Audit Intern Pemerintah Indonesia (2014) menetapkan Standar Audit Intern Pemerintah Indonesia untuk menjaga kualitas audit yang dilakukan oleh Aparat Pengawasan Intern Pemerintah (APIP). Menurut Standar Audit Intern Pemerintah Indonesia (2014) mengatur bahwa auditor harus memiliki pendidikan, pengetahuan, keahlian dan keterampilan, pengalaman serta kompetensi lain yang dibutuhkan untuk melaksanakan tanggung jawabnya. Pimpinan APIP harus yakin bahwa latar belakang pendidikan, kompetensi dan pengalaman auditor memadai untuk pekerjaan audit yang akan dilaksanakan.

Perencanaan audit merupakan tahap penting bagi auditor dalam setiap hendak melakukan audit baik dalam audit keuangan, audit kinerja maupun audit tujuan tertentu. Dalam setiap penugasan audit, auditor harus menyusun rencana audit. Rencana audit dimaksudkan untuk menjamin bahwa tujuan audit tercapai 
secara berkualitas, efisien dan efektif. Dalam merencanakan penugasan audit, auditor menetapkan sasaran, ruang lingkup, metodologi, dan alokasi sumber daya. Selain itu, auditor perlu mempertimbangkan berbagai hal termasuk sistem pengendalian intern dan ketaatan auditi terhadap peraturan perundang-undangan, kecurangan, dan ketidakpatuhan (abuse). Auditor harus mendokumentasikan rencana untuk setiap penugasan audit (AAIPI, 2014).

Badan Pengawasan Keuangan dan Pembangunan (BPKP) merupakan salah satu Aparat Pengawasan Intern Pemerintah (APIP) yang mempunyai tugas pokok dan fungsi melakukan pengawasan. Salah satu kegiatan pengawasan intern yang dilaksanakan oleh BPKP yaitu audit. BPKP dalam melaksanakan audit yang sebagaimana diamanatkan dalam Permenpan Nomor: PER/05/M.PAN/03/2008 mendasarkan pada standar audit yang telah ditetapkan termasuk standar umum audit kinerja dan audit investigatif. Standar audit yang diterapkan selain memberikan jaminan kualitas audit juga untuk menghindari adanya tuntutan dan ketidakpuasan terhadap hasil audit yang dilakukan oleh BPKP.

Contoh kasus yang terjadi pada Perwakilan BPKP Provinsi Bali, dimana terdapat hasil audit yang dipertanyakan hasilnya oleh stakeholders. Hasil audit penghitungan kerugian keuangan negara atas kasus tindak pidana korupsi pada Institit Hindu Darma Negeri (IHDN) Denpasar tahun 2012, dipertanyakan oleh Penasehat Hukum dan tersangka saat persidangan, karena hasil audit BPKP berbeda dengan hasil audit yang dilakukan oleh Badan Pemeriksa Keuangan, selain itu ahli dari BPKP yang dihadirkan di persidangan oleh Jaksa Penuntut 
Umum (JPU) dinilai bersifat tendensius dalam memberikan keterangan sehingga diragukan kualitas audit dan kompetensi auditor (Doso Sukendro, 2015).

Selain kasus IHDN di atas terdapat gugatan kepada hasil audit BPKP di Provinsi Riau dimana T. Azmun Jafar kepada jelajahriau.com di kediamannya Jl. Taman Sari, Pekanbaru mengatakan, "kami menggugat BPKP namun bukan menuntut instansi atau lembaganya akan tetapi produk hasil audit dari BPKP, karena dalam prosedurnya untuk menghasilkan produk BPKP, mereka seharusnya melakukan wawancara dan investigasi terlebih dahulu."dalam kasus saya ini, Pihak BPKP hanya berasusmsi atas laporan BAP Polisi saja, sehingga mereka mengeluarkan hasil produk audit yang tidak jelas" (www.Jelajahriau.com, 2016).

Kasus lain yang mempertanyakan kualitas audit juga terjadi atas hasil audit yang dilakukan oleh Badan Pemeriksa Keuangan dimana Komisi Pemberantasan Korupsi menginvestigasi hasil audit Badan Pemeriksa Keuangan Provinsi DKI Jakarta yang menyebutkan ada indikasi kerugian negara sebesar Rp.191 Miliar dalam pembelian lahan untuk Rumah Sakit Sumber Waras di Jakarta Barat oleh Pemerintah Jakarta. Investigasi ini untuk menguji kualitas audit (www.Suara.com, 2016).

Penelitian serupa yang dilakukan oleh Uswatun Hasanah (2013) mengenai pengaruh perencanaan audit dan pelatihan terhadap kualitas audit (studi pada Auditor Pemerintah di Inspektorat Kabupaten Jepara, Jawa Tengah) menyatakan bahwa perencanaan audit dan pelatihan teknis yang diikuti oleh pemeriksa secara simultan berpengaruh secara signifikan terhadap kualitas hasil audit dan Najib (2013) mengenai pengaruh keahlian, independensi, dan etika terhadap kualitas 
audit (studi pada Auditor Pemerintah di BPKP Perwakilan Provinsi Sul-Sel) menyatakan bahwa keahlian berpengaruh signifikan terhadap kualitas audit, independensi berpengaruh signifikan terhadap kualitas audit, etika berpengaruh signifikan terhadap kualitas audit.

Berdasarkan contoh kasus dan penelitian-penelitian tersebut, maka tujuan yang ingin dicapai dalam penelitian ini adalah untuk menganalisis pengaruh perencanaan audit pada kualitas audit di Perwakilan BPKP Provinsi Bali dan Menganalisis pengaruh kompetensi auditor pada kualitas audit di Perwakilan BPKP Provinsi Bali.

Teori pengambilan keputusan merupakan ilmu yang mempelajari tentang cara memilih alternatif yang tepat yang akan dijadikan sebuah keputusan dan berhubungan dengan perilaku seseorang dalam proses pengambilan keputusan (Siregar, 2013). Teori pengambilan keputusan menyatakan bahwa seseorang memiliki keterbatasan pengetahuan dan bertindak hanya berdasarkan persepsi terhadap situasi yang sedang dihadapi. Tiap orang memiliki struktur pengetahuan yang berbeda dan itu akan mempengarui cara pembuatan suatu keputusan dimana hal tersebut tidak dapat dilepaskan dari berbagai konteks sosial berupa tekanan dan pengaruh politik, sosial dan ekonomi.

Teori atribusi menurut Fritz Heider merupakan teori yang menjelaskan tentang perilaku seseorang. Teori ini mengacu tentang bagaimana seseorang menjelaskan penyebab perilaku orang lain atau dirinya sendiri yang disebabkan faktor internal misalnya sifat, karakter, sikap ataupun eksternal misalnya keadaan tertentu atau tekanan situasi yang akan memberikan pengaruh terhadap perilaku 
individu. Seseorang akan membentuk ide tentang orang lain dan situasi disekitarnya yang menyebabkan perilaku seseorang dalam persepsi sosial yang disebut dispositional atributions dan situational attributions (Lutrans, 2005).

Dalam lingkungan audit, perencanaan audit menjadi aktivitas utama yang auditor lakukan dengan tujuan untuk mencapai efisiensi laporan audit, mendapatkan penilaian kinerja audit yang baik dan meningkatkan keberhasilan audit yang secara eksplisit mencerminkan kualitas dari praktik audit. Christ (1993) dalam Ussahawanitchakit (2012) mendefinisikan perencanan audit sebagai pengembangan dari strategi audit yang diperlukan untuk keadaan yang didasari pada ekspektasi tentang kemungkinan kesalahan dalam laporan keuangan, sehingga perencanaan audit terdiri dari lima unsur utama yaitu pencarian informasi latar belakang klien, penilaian tingkat materialitas, penilaian risiko, peninjauan analisis awal, dan pemahaman struktur pengendalian internal.

Mendukung hal tersebut, dalam penelitian yang dilakukan oleh Kurniawan (2010) dalam penelitiannya; Pengaruh Perencanaan dan Tekanan Anggaran Waktu (Time Budget Pressure) terhadap Kualitas Hasil Pemeriksaan Laporan Keuangan Pemerintah Daerah; menyimpulkan bahwa perencanaan pemeriksaan yang dilakukan oleh pemeriksa berpengaruh positif secara signifikan terhadap kualitas audit. Berdasarkan teori dan penelitian sebelumnya dapat dijelaskan bahwa semakin tinggi tingkat ketepatan perencanaan audit, maka kualitas audit yang dihasilkan menjadi semakin baik.

$\mathrm{H}_{1}$ : Perencanaan audit berpengaruh positif pada kualitas audit. 
Menurut Lastanti dalam Najib (2013) mengartikan keahlian atau kompetensi sebagai seorang yang memiliki pengetahuan dan keterampilan prosedural yang luas yang ditunjukkan dalam pengalaman audit. Sehingga dapat diartikan bahwa kompetensi auditor adalah auditor yang dengan pengetahuan dan pengalaman yang cukup dan eksplisit dapat melakukan audit secara objektif, cermat dan seksama.

Menurut Artha (2014) kompetensi auditor sebagai seseorang yang memiliki pengetahuan yang luas, pendidikan serta ketrampilan yang tinggi serta ditambah dengan pengalaman audit yang dimilikinya. Kompetensi seorang auditor dalam mengaudit mencerminkan tingkat pengetahuan, pengalaman, dan pendidikan yang dimiliki auditor. Semakin tinggi kompetensi seorang auditor, maka kualitas audit yang dihasilkan oleh auditor akan semakin akurat. Seorang auditor yang memiliki kompetensi tinggi akan mampu menghadapi tugas audit, mengolah informasi yang relevan dan menganalisis bukti-bukti audit sehingga dapat menunjang pemberian judgement yang akurat untuk menentukan kualitas dari hasil audit dan juga opini yang akan dinyatakan oleh auditor.

Najib (2013) dalam penelitiannya mengenai "Pengaruh Keahlian, Independensi, dan Etika Terhadap Kualitas Audit" menyimpulkan bahwa keahlian berpengaruh signifikan terhadap kualitas audit, independensi berpengaruh signifikan terhadap kualitas audit, dan etika berpengaruh signifikan terhadap kualitas audit. Keahlian, independensi, dan etika tidak berpengaruh secara bersama-sama terhadap kualitas audit. Independensi dan etika yang berpengaruh secara signifikan terhadap kualitas audit, sedangkan keahlian tidak 
ikut berperan didalamnya. Berdasarkan teori dan penelitian sebelumnya dapat dijelaskan bahwa semakin tinggi tingkat kompetensi auditor, maka kualitas audit yang dihasilkan menjadi semakin baik.

$\mathrm{H}_{2}$ : Kompetensi auditor berpengaruh positif pada kualitas audit

Berdasarkan landasan teori dan kajian empiris pada penelitian terdahulu, maka secara sistematis, kerangka konseptual dalam penelitian dapat digambarkan sebagai berikut:

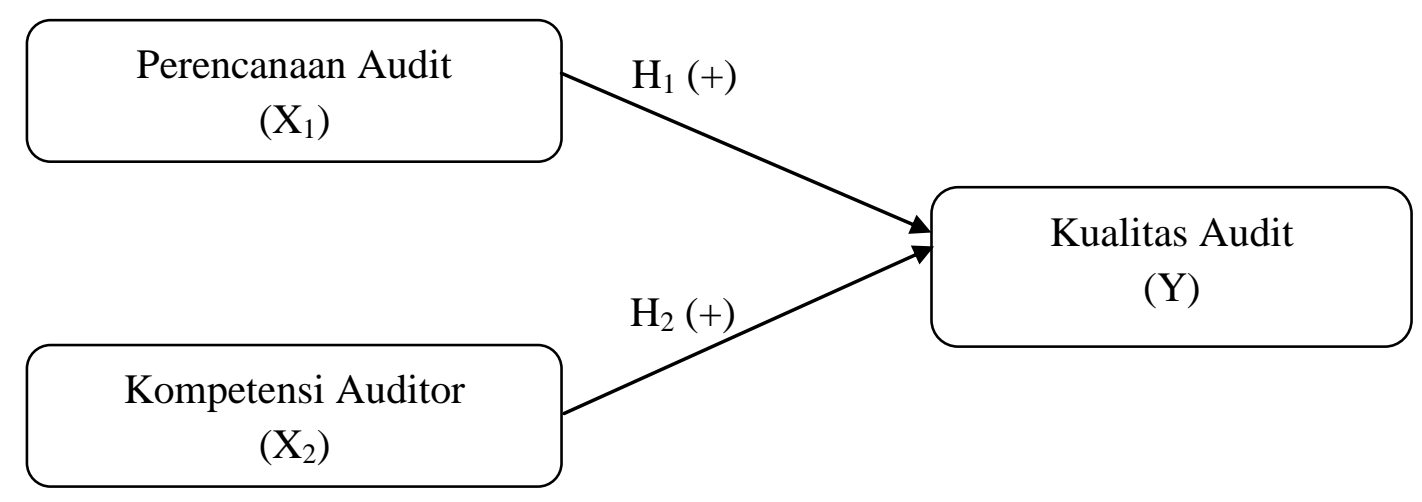

\section{Gambar 1. Kerangka Konseptual}

\section{METODE PENELITIAN}

Penelitian ini merupakan penelitian asosiatif kuantitatif yaitu penelitian yang meneliti pengaruh suatu variabel terhadap variabel lainnya atau mengetahui hubungan antar variabel. Pada penelitian ini variabel yang diuji adalah perencanaan audit, kompetensi auditor dan kualitas audit.

Penelitian ini dilakukan di Perwakilan BPKP Provinsi Bali dengan alasan keterjangkauan lokasi penelitian baik dari segi tenaga, dana maupun dari segi efisiensi waktu. Adapun alasan lain yang tidak kalah penting karena Perwakilan BPKP Provinsi Bali merupakan instansi vertikal BPKP yang mempunyai tugas pokok melaksanakan pengawasan (audit) intern terhadap akuntabilitas keuangan 
negara dan atau daerah. Berdasarkan pertimbangan tersebut, Perwakilan BPKP Provinsi Bali diperkirakan dapat mewakili masalah pokok dalam penelitian ini.

Obyek penelitian ini adalah kualitas audit yang dipengaruhi oleh perencanaan audit dan kompetensi auditor di Perwakilan BPKP Provinsi Bali, dan Perwakilan BPKP Provinsi Bali. Variabel bebas dalam penelitian ini adalah Perencanaan Audit dan Kompetensi Auditor. Perencanaan audit diukur dengan instrumen yang dikembangkan dalam Standar Audit Intern Pemerintah Indonesia oleh AAIPI (2014) yang terdiri dari 6 (enam) item pernyataan. Sedangkan Kompetensi auditor diukur dengan instrumen yang dikembangkan oleh Hakim (2011) yang terdiri dari 6 (enam) item pernyataan.

Variabel terikat dalam penelitian ini adalah Kualitas Audit. Audit yang berkualitas berarti pelaksanaan audit memenuhi standar audit yang ditetapkan. Variabel kualitas audit (Y) diuraikan sebagai kegiatan audit kinerja dan audit dengan tujuan tertentu (diluar audit keuangan) yang dilakukan oleh BPKP. Indikator yang digunakan untuk mengukur kualitas audit adalah standar penyusunan kertas kerja, supervisi berjenjang, pelaporan, dan pemantauan. Kualitas audit diukur dengan instrumen yang dikembangkan oleh Najib (2013) yang terdiri dari 13 (tiga belas) item pernyataan.

Populasi yang diteliti dalam penelitian ini adalah pemeriksa yang bekerja di Perwakilan BPKP Provinsi Bali. Penentuan sampel menggunakan purposive sampling yaitu teknik penentuan sampling dengan pertimbangan tertentu (Sugiyono, 2013). Kriteria sampel yang akan dijadikan sumber data adalah 40 pemeriksa pria dan 37 pemeriksa wanita yang memiliki sertifikasi sebagai Jabatan 
Fungsional Auditor (JFA) dan tidak sedang menjalani pendidikan/tugas belajar di luar Bali, berusia diantara 20 tahun sampai dengan 60 tahun, memiliki tingkat pendidikan minimal Diploma III sampai dengan S2, dengan masa kerja diantara kurang dari 5 tahun sampai dengan lebih dari 20 tahun.

Metode pengumpulan data yang digunakan dalam penelitian ini adalah metode survei dengan teknik kuesioner. Kuesioner akan diantarkan langsung ke lokasi penelitian yang kemudian akan diisi oleh auditor yang bekerja di Perwakilan BPKP Provinsi Bali. Kuesioner ini terdiri atas pernyataan mengenai pengaruh perencanaan audit, kompetensi auditor dan kualitas audit yang diberikan kepada responden untuk dijawab.

Data yang sudah terkumpul kemudian dianalisis menggunakan program SPSS (Statistical Product and Service Solution). Oleh karena dalam penetian ini menggunakan kuesioner sebagai instrumen penelitian, maka tahapan analisis yang pertama adalah melakukan uji instrumen penelitian yang terdiri dari uji validitas dan uji reliabilitas. Selanjutnya melakukan Uji Asumsi Klasik sebagai prasyarat uji sebelum melakukan pengujian regresi. Kemudian untuk melihat pengaruh perencanaan audit dan kompetensi auditor pada kualitas audit di Perwakilan BPKP Provinsi Bali digunakan analisis regresi linier berganda. Model regresi linier berganda ditunjukkan dalam persamaan berikut.

$\mathrm{Y}=\mathrm{a}+\mathrm{b}_{1} \mathrm{X}_{1}+\mathrm{b}_{2} \mathrm{X}_{2}+e$

Dimana:

$\mathrm{Y} \quad=$ Kualitas audit

$\mathrm{a} \quad=$ Konstanta

$\mathrm{X}_{1} \quad=$ Perencanaan Audit

$\mathrm{X}_{2}=$ Kompetensi Auditor 
$\mathrm{b}_{1}-\mathrm{b}_{2}=$ Koefisien regresi

$e \quad=$ Standar error

\section{HASIL DAN PEMBAHASAN}

Data dalam penelitian ini diperoleh dengan menyebarkan kuesioner secara langsung kepada 79 pemeriksa di Perwakilan BPKP Provinsi Bali pada tanggal 26 Maret 2018 sampai dengan 6 April 2018. Pemeriksa yang diberikan kuesioner adalah pemeriksa yang memiliki sertifikasi Jabatan Fungsional Auditor (JFA) dan pemeriksa yang tidak sedang menjalani pendidikan/tugas belajar di luar Bali saat dilakukan pengambilan sampel. Pada tanggal 6 April 2018, kuesioner yang terkumpul sebanyak 77 kuesioner. Dua pemeriksa yang tidak mengisi kuesioner tersebut disebabkan karena sedang menjalani pendidikan/tugas belajar S2 di Universitas Airlangga, Surabaya, dan satu lagi sedang menjalani pendidikan/tugas belajar S1 di Universitas Jenderal Soedirman, Purwokerto.

Profil responden penelitian berdasarkan jenis kelamin, usia, tingkat pendidikan dan masa kerja disajikan pada Tabel 1 sebagai berikut :

Tabel 1.

Profil Responden

\begin{tabular}{cccc}
\hline & Keterangan & Jumlah Responden & Persentase \\
\hline Jenis & Pria & 40 & $51,95 \%$ \\
Kelamin & Wanita & 37 & $48,05 \%$ \\
& Jumlah & 77 & $100,00 \%$ \\
\multirow{2}{*}{ Usia } & $20-30$ tahun & 12 & $15,58 \%$ \\
& $31-40$ tahun & 14 & $18,18 \%$ \\
& $41-50$ tahun & 38 & $49,35 \%$ \\
Tingkat & $51-60$ tahun & 13 & $16,88 \%$ \\
Pendidikan & Jumlah & 77 & $100,00 \%$ \\
& D3/Sederajat & 15 & $19,48 \%$ \\
& S1/Sederajat & 58 & $75,32 \%$ \\
Masa Kerja & Jumlah & 4 & $5,19 \%$ \\
& $<5$ tahun & 77 & $100,00 \%$ \\
& $5-10$ tahun & 11 & $14,29 \%$
\end{tabular}




\begin{tabular}{ccc}
$11-15$ tahun & 6 & $7,79 \%$ \\
$16-20$ tahun & 32 & $41,56 \%$ \\
$>20$ tahun & 25 & $32,47 \%$ \\
Jumlah & 77 & $100,00 \%$ \\
\hline
\end{tabular}
Sumber : Data diolah, 2018

Berdasarkan Tabel 1 dapat diketahui dari 77 responden sebanyak 40 orang $(51,95 \%)$ pria, dan responden wanita dengan jumlah 37 orang $(48,05 \%)$. Profil responden berdasarkan usia menunjukkan bahwa responden yang berusia 20-30 tahun sebanyak 12 orang (15,58\%), berusia 31-40 Tahun sebanyak 14 orang $(18,18 \%)$, berusia $41-50$ tahun sebanyak 38 orang $(49,35 \%)$ dan berusia $51-$ 60 tahun sebanyak 13 orang $(16,88 \%)$.

Profil responden berdasarkan tingkat pendidikan menunjukkan bahwa sebagian besar responden berlatar belakang pendidikan S1/DIV sebanyak 58 orang $(75,32 \%)$, responden lulusan D3/sederajat sebanyak 15 orang (19,48\%), sedangkan responden lulusan S2 sebanyak 4 orang $(5,19 \%)$.

Profil responden berdasarkan masa kerja menunjukkan bahwa responden yang memiliki masa kerja kurang dari 5 tahun sebanyak 11 orang (14,29\%), responden dengan masa kerja 5 sampai dengan 10 tahun sebanyak 3 orang $(3,90 \%)$, responden dengan masa kerja 11 sampai dengan 15 tahun sebanyak 6 orang $(7,79 \%)$, responden dengan masa kerja 16 sampai dengan 20 tahun sebanyak 32 orang (41,56\%), dan responden dengan masa kerja lebih dari 20 tahun sebanyak 25 orang $(32,47 \%)$.

Analisis statistik deskriptif digunakan untuk memberikan informasi mengenai karakteristik variabel penelitian. Statistik deskriptif menjelaskan skala jawaban responden pada setiap variabel independen yang diukur dari nilai 
minimum, nilai maksimum, nilai tengah (mean) dan standar deviasi. Hasil uji statistik descriptive disajikan pada Tabel 2.

Tabel 2.

Hasil Uji Statistik Descriptive

\begin{tabular}{|c|c|c|c|c|c|c|}
\hline & \multirow{2}{*}{$\begin{array}{l}\mathbf{N} \\
\text { Statistic }\end{array}$} & \multirow{2}{*}{$\begin{array}{c}\text { Minimum } \\
\text { Statistic }\end{array}$} & \multirow{2}{*}{$\begin{array}{l}\text { Maximum } \\
\text { Statistic }\end{array}$} & \multicolumn{2}{|c|}{ Mean } & \multirow{2}{*}{$\begin{array}{c}\text { Std } \\
\text { Deviation } \\
\text { Statistic }\end{array}$} \\
\hline & & & & Statistic & $\begin{array}{l}\text { Std. } \\
\text { Error }\end{array}$ & \\
\hline Kualitas_Audit & 77 & 48 & 65 & 57,42 & 0,616 & 5,408 \\
\hline Perencanaan & 77 & 22 & 30 & 26,27 & 0,292 & 2,558 \\
\hline Kompetensi & 77 & 22 & 30 & 26,08 & 0,300 & 2,630 \\
\hline $\begin{array}{l}\text { Valid N } \\
\text { (listwise) }\end{array}$ & 77 & & & & & \\
\hline
\end{tabular}

Sumber : Data diolah, 2018

Berdasarkan Tabel 2 menunjukkan bahwa dari 77 responden nilai maksimum untuk kualitas audit sebesar 65 dan nilai minimum sebesar 48 dengan nilai tengah sebesar 57,42. Nilai maksimum untuk perencanaan audit sebesar 30 dengan nilai minimum 22 dan nilai tengah sebesar 26,27. Nilai maksimum untuk kompetensi auditor sebesar 30 dengan nilai minimum 22 dan nilai tengah sebesar 26,08 .

Pengujian validitas dalam penelitian ini menggunakan teknik corrected item-total correlation. Pengujian validitas isi instrumen dilakukan dengan cara menghitung korelasi antara skor butir instrumen dengan skor total. Suatu instrument dinyatakan valid apabila koefisien korelasi $r_{\text {hitung }}$ lebih besar dibandingkan koefisien korelasi $r_{\text {tabel }}$ pada tingkat signifikansi 5\%. Dengan jumlah sampel penelitian sebanyak 77 responden, maka nilai $r_{\text {tabel }}$ yang didapat sebesar 0,2242 Hal ini berarti suatu butir pernyataan dianggap valid apabila memiliki

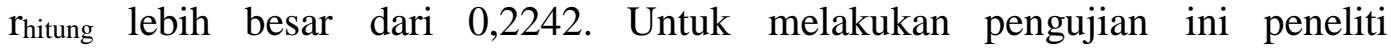


menggunakan bantuan aplikasi SPSS 13.0. Hasil uji validitas variabel penelitian ini disajikan pada Tabel 3.

Tabel 3

Hasil Uji Validitas

\begin{tabular}{|c|c|c|c|c|c|}
\hline \multicolumn{6}{|c|}{ Corrected Item-Total Correlation } \\
\hline \multicolumn{2}{|c|}{ Perencanaan Audit (X1) } & \multicolumn{2}{|c|}{$\begin{array}{l}\text { Kompetensi Auditor } \\
\left(\mathbf{X}_{2}\right)\end{array}$} & \multicolumn{2}{|c|}{$\begin{array}{c}\text { Kualitas Audit } \\
\text { (Y) }\end{array}$} \\
\hline $\mathrm{X} 1.1$ & 0,676 & $\mathrm{X} 2.1$ & 0,690 & Y1 & 0,609 \\
\hline $\mathrm{X} 1.2$ & 0,725 & $\mathrm{X} 2.2$ & 0,588 & Y2 & 0,697 \\
\hline $\mathrm{X} 1.3$ & 0,697 & $\mathrm{X} 2.3$ & 0,677 & Y3 & 0,668 \\
\hline $\mathrm{X} 1.4$ & 0,719 & $\mathrm{X} 2.4$ & 0,674 & Y4 & 0,675 \\
\hline $\mathrm{X} 1.5$ & 0,580 & $\mathrm{X} 2.5$ & 0,722 & Y5 & 0,745 \\
\hline \multirow[t]{8}{*}{$\mathrm{X} 1.6$} & 0,746 & X2.6 & 0,586 & Y6 & 0,793 \\
\hline & & & & Y7 & 0,785 \\
\hline & & & & Y8 & 0,790 \\
\hline & & & & Y9 & 0,767 \\
\hline & & & & Y10 & 0,840 \\
\hline & & & & Y11 & 0,744 \\
\hline & & & & Y12 & 0,651 \\
\hline & & & & Y13 & 0,510 \\
\hline
\end{tabular}

Sumber : Data diolah, 2018

Tabel 3 menunjukkan bahwa nilai Corrected item total corelation pada seluruh pernyataan yang membangun variabel perencanaan audit $\left(\mathrm{X}_{1}\right)$, kompetensi auditor $\left(\mathrm{X}_{2}\right)$ dan kualitas audit $(\mathrm{Y})$ memiliki $\mathrm{r}_{\text {hitung }}$ yang lebih besar dari pada $\mathrm{r}_{\text {tabel }}$ (0,2242). Hal ini berarti setiap butir pernyataan yang menyusun variabel perencanaan audit dalam kuesioner dinyatakan valid.

Setelah kuesioner dinyatakan valid pada pengukuran validitas, selanjutnya dilakukan pengujian reliabilitas. Reliabilitas merupakan alat untuk mengukur apakah kuesioner yang digunakan andal. Suatu alat ukur disebut mempunyai reliabilitas tinggi atau dapat dipercaya jika alat ukur itu mantap dalam pengertian alat ukur tersebut stabil, dapat diandalkan, dan dapat diramalkan. Pengujian reliabilitas dalam penelitian ini menggunakan cronbach alpha $(\alpha)$. Koefisien 
cronbach alpha yang lebih dari 0,70 menunjukkan keandalan (reliabilitas) instrumen. Selain itu, nilai koefisien cronbach alpha yang semakin mendekati 1 menunjukkan semakin tinggi konsistensi internal reliabilitasnya. Didalam pengujian reliabilitas penulis menggunakan bantuan SPSS 13.0. Hasil uji Reliabilitas variabel penelitian disajikan pada Tabel 4.

Tabel 4.

Hasil Uji Reliabilitas Variabel Penelitian

\begin{tabular}{lccc}
\hline \multicolumn{1}{c}{ Variabel } & Croncbach Alpha & Sandar Reliabilitas & Keterangan \\
\hline Perencanaan & 0,878 & 0,700 & Reliabel \\
Kompetensi & 0,850 & 0,700 & Reliabel \\
Kualitas Audit & 0,938 & 0,700 & Reliabel \\
\hline
\end{tabular}

Sumber : Data diolah, 2018

Tabel 4 menunjukkan bahwa nilai cronbach alpha $(\alpha)$ untuk masingmasing variabel adalah lebih dari 0,70. Dengan demikian dapat disimpulkan bahwa butir-butir pernyataan kuesioner dalam setiap variabel adalah reliabel (dapat diandalkan).

Teknik pengujian yang digunakan untuk melihat pengaruh perencanaan audit dan kompetensi auditor pada kualitas audit di Perwakilan BPKP Provinsi Bali dalm penelitian ini menggunakan analisis regresi linier berganda. Sebelum dilakukan analisis regresi linier berganda, maka dilakukan pengujian asumsi klasik terlebih dahulu. Uji asumsi klasik yang dilakukan dalam penelitian ini terdiri dari uji normalitas, uji multikolinieritas, uji heteroskedastisitas dan uji autokorelasi.

Hasil uji normalitas dalam penelitian ini dilihat dari hasil uji Normal P-P Plot yang disajikan pada Gambar 2. 


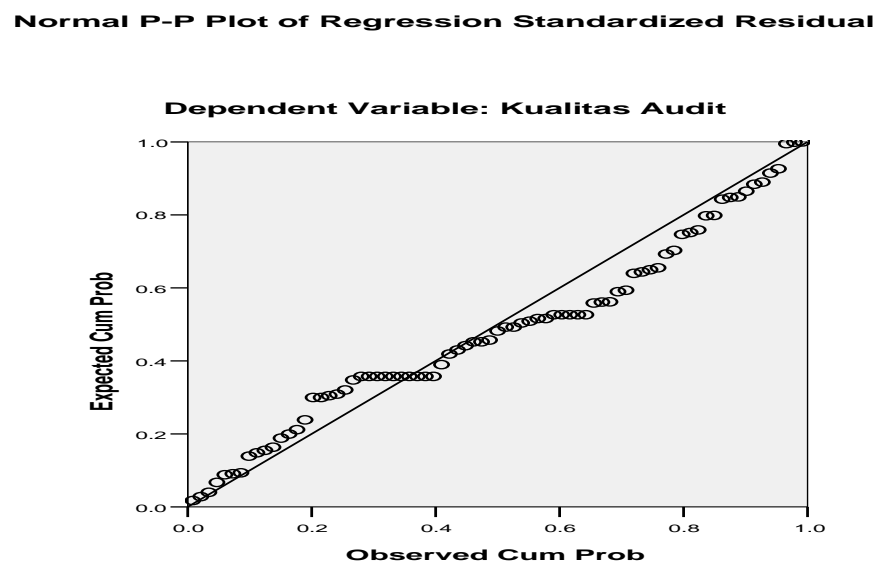

Gambar 2. Hasil Uji Normalitas

Berdasarkan Gambar 2 terlihat bahwa data menyebar di sekitar diagram dan mengikuti model regresi. Sehingga berdasarkan uji Normal P-P Plot dapat disimpulkan bahwa data yang diolah merupakan data yang normal sehingga uji normalitas terpenuhi.

Tabel 5.

Hasil Uji Multikolinearitas

\begin{tabular}{|c|c|c|c|c|c|c|c|}
\hline \multirow{2}{*}{ Model } & \multicolumn{2}{|c|}{$\begin{array}{l}\text { Unstandardized } \\
\text { Coefficients }\end{array}$} & \multirow{2}{*}{$\begin{array}{c}\begin{array}{c}\text { Standardized } \\
\text { Coefficients }\end{array} \\
\text { Beta }\end{array}$} & \multirow{2}{*}{$\mathbf{t}$} & \multirow{2}{*}{ Sig. } & \multicolumn{2}{|c|}{$\begin{array}{c}\text { Collinearity } \\
\text { Statistics }\end{array}$} \\
\hline & B & $\begin{array}{c}\text { Std. } \\
\text { Error }\end{array}$ & & & & Tolerance & VIF \\
\hline (Constant) & 0,034 & 3,828 & & 1,576 & 0,119 & & \\
\hline Perencanaan Audit & 1,497 & 0,153 & 0,708 & 9,762 & 0,000 & 0,712 & 1,405 \\
\hline Kompetensi Auditor & 0,462 & 0,149 & 0,225 & 3,095 & 0,003 & 0,712 & 1,405 \\
\hline
\end{tabular}

Berdasarkan Tabel 5 terlihat bahwa hasil uji multikolinearitas menunjukkan masing-masing variabel bebas memiliki nilai tolerance lebih besar dari 0,10 dan nilai VIF lebih kecil dari 10. Berdasarkan nilai tolerance dan nilai VIF dari masing-masing variabel bebas tersebut, maka dapat disimpulkan bahwa tidak ada multikolinearitas antar variabel bebas dalam model regresi.

Hasil uji Heteroskedastisitas dalam penelitian ini dapat dilihat dari hasil uji Scatterplot yang disajikan pada Gambar 3 


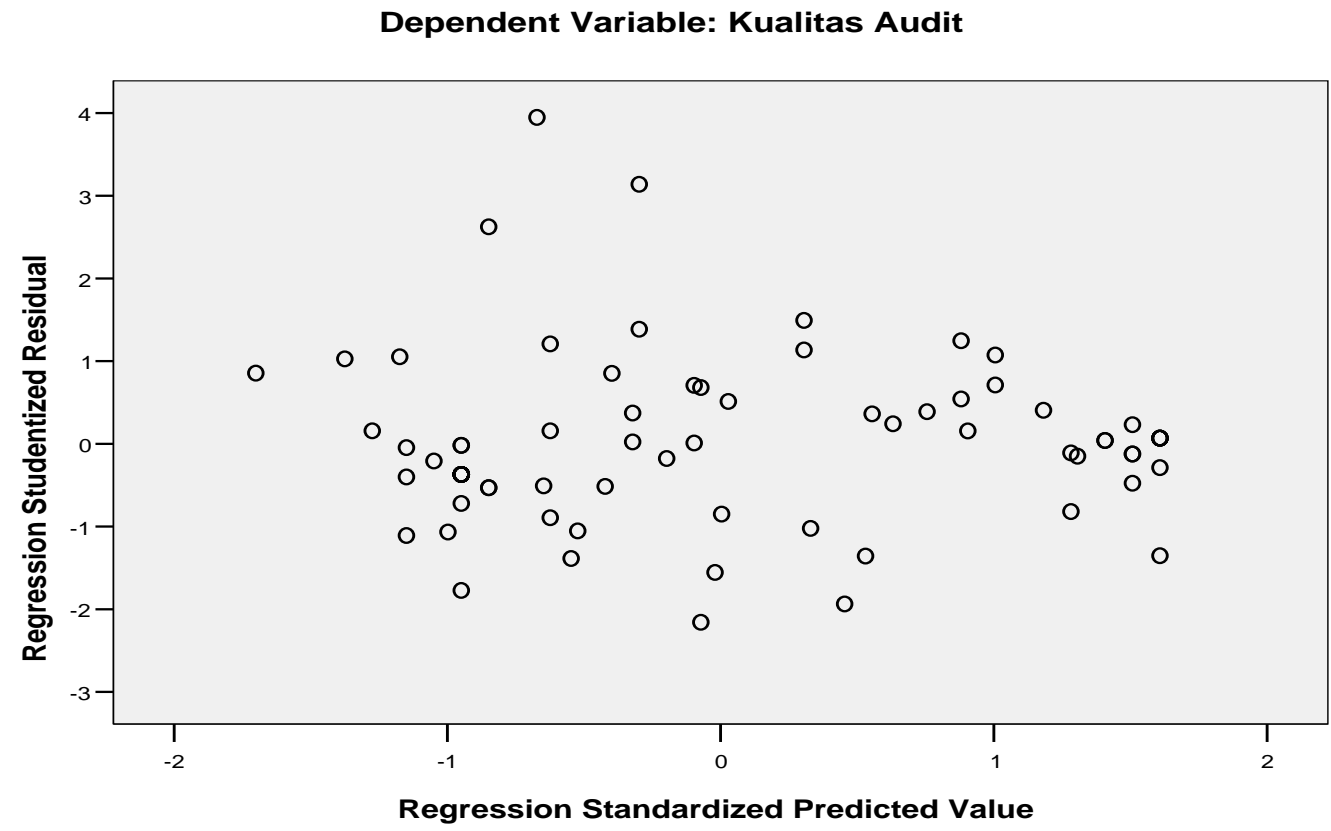

Gambar 3. Hasil Uji Heteroskedastisitas

Dari Gambar 3 dapat diketahui bahwa tidak terjadi heteroskedastisitas sebab tidak ada pola yang jelas serta titik-titik menyebar di atas dan di bawah angka 0 pada sumbu Y sehingga dapat dikatakan uji heteroskedastisitas terpenuhi.

Uji asumsi klasik yang terakhir adalah uji autokorelasi. Uji autokorelasi merupakan pengujian asumsi dalam regresi dimana variabel dependen tidak berkorelasi dengan dirinya sendiri. Hasil uji autokorelasi dalam penelitian ini disajikan pada Tabel 6 .

Tabel 6.

Hasil Uji Autokorelasi

\begin{tabular}{|c|c|c|c|c|c|c|c|c|c|c|}
\hline & \multirow[b]{2}{*}{$\mathbf{R}$} & \multirow[b]{2}{*}{$\begin{array}{c}\text { R } \\
\text { Square }\end{array}$} & \multirow[b]{2}{*}{$\begin{array}{c}\text { Adjust- } \\
\text { ed R } \\
\text { Square }\end{array}$} & \multirow[b]{2}{*}{$\begin{array}{c}\text { Std. Error } \\
\text { of the } \\
\text { Estimate } \\
\end{array}$} & \multicolumn{5}{|c|}{ Change Statistics } & \multirow[b]{2}{*}{$\begin{array}{l}\text { Durbin- } \\
\text { Watson }\end{array}$} \\
\hline & & & & & $\begin{array}{c}\text { R } \\
\text { Square } \\
\text { Change } \\
\end{array}$ & $\begin{array}{c}\text { F } \\
\text { Change }\end{array}$ & $\begin{array}{c}\text { df } \\
1\end{array}$ & $\begin{array}{c}\text { df } \\
2\end{array}$ & $\begin{array}{c}\text { Sig. F } \\
\text { Change }\end{array}$ & \\
\hline 1 & $0,850^{\mathrm{a}}$ & 0,723 & 0,715 & 2,886 & 0,723 & 96,432 & 2 & 74 & 0,000 & 1,296 \\
\hline
\end{tabular}

Sumber : Data diolah, 2018 
Tabel 6 menunjukkan nilai Durbin-Watson (DW hitung) sebesar 1,296. Berdasarkan kriteria yang telah ditentukan DW hitung berada diantara -2 dan 2 , yakni $-2 \leq 1,296 \leq 2$ maka ini berarti tidak terjadi autokorelasi. Sehingga kesimpulannya adalah Uji Autokorelasi terpenuhi. Oleh karena seluruh uji asumsi klasik dalam penelitian ini sudah memenuhi syarat, maka analisis regresi layak dilakukan lebih lanjut. Hasil uji regresi linier berganda dalam penelitian ini disajikan dalam Tabel 7 sebagai berikut:

Tabel 7.

Hasil Uji Regresi Linier Berganda

\begin{tabular}{llccccc}
\hline \multirow{2}{*}{ Model } & \multicolumn{2}{c}{$\begin{array}{c}\text { Unstandardized } \\
\text { Coefficients }\end{array}$} & $\begin{array}{c}\text { Standardized } \\
\text { Coefficients }\end{array}$ & \multirow{2}{*}{ Sig. } \\
\cline { 2 - 5 } & & B & Std. Error & Beta & & \\
\hline 1 & (Constant) & 6,034 & 3,8286 & & 1,576 & 0,119 \\
& Perencanaan Audit & 1,497 & 0,153 & 0,708 & 9,762 & 0,000 \\
& Kompetensi Auditor & 0,462 & 0,149 & 0,225 & 3,095 & 0,003 \\
\hline & Adjusted R Square & 0,715 & & & & \\
& F Statistik & 96,432 & & & & \\
Signifikansi Uji F & 0,000 & & & & & \\
\hline
\end{tabular}

Sumber : Data diolah, 2018

Tabel 7 menunjukkan pengaruh perencanaan audit pada kualitas audit memiliki nilai signifikansi $t_{\text {hitung }}$ sebesar 0,000 lebih kecil dari pada $\alpha=0,05$ maka $\mathrm{H}_{0}$ ditolak dan $\mathrm{H}_{1}$ diterima. Hal ini membuktikan bahwa perencanaan audit berpengaruh positif dan signifikan pada kualitas audit. Hasil uji regresi linier berganda pada Tabel 7 juga menunjukkan nilai signifikansi thitung untuk pengaruh kompetensi auditor pada kualitas audit sebesar 0,003 lebih kecil dari pada $\alpha=$ 0,05 maka $\mathrm{H}_{0}$ ditolak dan $\mathrm{H}_{2}$ diterima. Hal ini membuktikan bahwa kompetensi auditor berpengaruh positif dan signifikan pada kualitas audit 
Berdasarkan Tabel 7 diketahui nilai Adjusted $R$ Square pada persamaan regresi ini sebesar 0,715. Nilai Adjusted $R$ Square berarti bahwa 71,5\% variasi kualitas audit Perwakilan BPKP Provinsi Bali mampu dijelaskan oleh model yang dibentuk oleh perencanaan audit dan kompetensi auditor. Sedangkan sisanya sebesar $28,5 \%$ dijelaskan oleh faktor lain di luar model penelitian ini.

Tabel 7 juga menunjukkan bahwa hasil uji $\mathrm{F}$ memiliki nilai signifikan $\mathrm{F}$ Change sebesar 0,000 lebih kecil dari 0,05. Hal ini menunjukkan bahwa model penelitian ini layak digunakan sebagai model regresi.

Hasil uji regresi linier berganda menunjukkan adanya pengaruh positif dan signifikan perencanaan audit pada kualitas audit di Perwakilan BPKP Provinsi Bali. Hal ini mendukung penelitian Zulfadli Abidi, Nadirsyah, dan Heru Fahlevi (2016) serta Kurniawan (2010). Standar Audit Intern Pemerintah Indonesia oleh AAIPI (2014) menyatakan bahwa dalam perencanaan penugasan audit, auditor harus mengembangkan dan mendokumentasikan rencana untuk setiap penugasan, termasuk tujuan, ruang lingkup, waktu, dan alokasi sumber daya penugasan.. Dalam pedoman perencanaan penugasan audit (Pusat Pendidikan dan Pelatihan Pengawasan BPKP, 2010), dinyatakan bahwa data yang dimuat dalam dokumen perencanaan audit antara lain identitas auditan, anggaran biaya, sasaran audit, periode audit, jumlah auditor, waktu mulai audit, dan waktu penerbitan laporan hasil audit.

Berdasarkan hasil uji regresi linear berganda pada tabel 4.12 dapat dilihat bahwa nilai koefisien regresi perencanaan audit $\left(b_{1}\right)$ bernilai positif sebesar 1,497 yang memiliki arti bahwa perencanaan audit berbanding lurus dengan kualitas 
audit, dimana ketika variabel perencanaan audit meningkat maka nilai kualitas audit akan meningkat sebesar 1,497. Tingkat signifikansi thitung perencanaan audit sebesar 0,000 lebih kecil dari pada $\alpha=0,05$ yang memiliki arti bahwa perencanaan audit berpengaruh positif dan signifikan pada kualitas audit

Hal tersebut terjadi karena perencanaan audit menjadi aktivitas utama yang dilakukan auditor dengan tujuan untuk mencapai efisiensi laporan audit, mendapat penilaian kinerja audit yang baik dan mencerminkan kualitas audit dari praktik audit (Ussahawanitchakit, 2012). Rencana penugasan audit juga dimaksudkan untuk menjamin bahwa tujuan audit tercapai secara berkualitas, ekonomis, efisien dan efektif (Pusdiklatwas BPKP, 2010), sehingga dapat dikatakan bahwa perencanaan audit berpengaruh positif pada kualitas audit yang berarti bahwa semakin tinggi tingkat ketepatan perencanaan audit, maka kualitas audit yang dihasilkan menjadi semakin baik.

Hasil uji regresi linier berganda menunjukkan adanya pengaruh positif dan signifikan kompetensi auditor pada kualitas audit di Perwakilan BPKP Provinsi Bali. Hal ini mendukung penelitian Hakim (2011) dan Daeng Achmad Ardiansyah (2014). Standar Audit Aparat Pengawasan Intern Pemerintah (APIP) yang diatur dalam Permenpan Nomor PER/05/M.PAN/03/2008 menyatakan bahwa auditor harus mempunyai pengetahuan, ketrampilan, dan kompetensi lainnya diperlukan untuk melaksanakan tanggung jawabnya.

Berdasarkan hasil uji regresi linear berganda pada tabel 4.12 dapat dilihat bahwa nilai koefisien regresi kompetensi auditor $\left(b_{2}\right)$ bernilai positif sebesar 0,462 yang memiliki arti bahwa kompetensi auditor berbanding lurus dengan kualitas 
audit, dimana ketika variabel kompetensi auditor meningkat maka nilai kualitas audit akan meningkat sebesar 0,462. Tingkat signifikansi thitung kompetensi auditor sebesar 0,003 lebih kecil dari pada $\alpha=0,05$ yang memiliki arti bahwa kompetensi auditor berpengaruh positif dan signifikan pada kualitas audit

Hal tersebut terjadi karena auditor yang memiliki kompetensi tinggi akan mampu menghadapi tugas audit, mengolah informasi yang relevan dan menganalisis bukti-bukti audit sehingga dapat menunjang pemberian judgement yang akurat untuk menentukan kualitas dari hasil audit dan juga opini yang akan dinyatakan oleh auditor (Artha, 2014), sehingga dapat dikatakan bahwa kompetensi auditor berpengaruh positif pada kualitas audit yang berarti bahwa semakin tinggi kompetensi auditor, maka kualitas audit yang dihasilkan menjadi semakin baik.

Pejabat fungsional auditor Perwakilan BPKP Bali minimal memiliki tingkat pendidikan formal Diploma III dan memiliki sertifikasi jabatan fungsional auditor. Perwakilan BPKP Provinsi Bali dalam meningkatkan kompetensi auditornya dilakukan dengan memberikan kesempatan kepada auditornya untuk menempuh pendidikan formal yang lebih tinggi dengan memberikan ijin belajar maupun kesempatan mengikuti tugas belajar melalui beasiswa DIV STAN, Star Pro maupun SPIRIT.

Auditor Perwakilan BPKP Provinsi Bali sebelum menjadi auditor harus mengikuti pendidikan dan latihan (diklat) penjenjangan auditor yang terdiri dari, diklat penjenjangan auditor terampil/pertama, auditor muda dan auditor madya. Diklat pembentukan auditor dilakukan secara berjenjang dimulai dari 
pembentukan auditor terampil atau auditor pertama untuk auditor yang akan diperankan sebagai anggota tim. Diklat penjenjangan auditor muda diperuntukan bagi auditor yang diperankan sebagai ketua tim. Diklat penjenjangan auditor madya diperuntukkan bagi auditor yang diperankan sebagai pengendali teknis.

Perwakilan BPKP Provinsi Bali selama ini telah menjaga dan terus mengembangkan kompetensi auditornya dengan program yang telah dijelaskan di atas. Kompetensi auditor Perwakilan BPKP Provinsi Bali dapat dikatakan baik, meskipun demikian berdasarkan Tabel 4.3 tentang profil responden berdasarkan tingkat pendidikan bahwa sebagian besar auditor Perwakilan BPKP Provinsi Bali berlatar pendidikan S1/sederajat, dengan prosentase sebanyak 75,32\% dan masih terdapat auditor yang berpendidikan Sarjana Muda atau D3.

Berdasarkan hasil uji regresi linear berganda pada tabel 4.12 dapat dijelaskan bahwa kualitas audit di Perwakilan BPKP Provinsi Bali dipengaruhi oleh perencanaan audit dan kompetensi auditor dengan nilai koefisien regresi perencanaan audit (b1) bernilai positif sebesar 1,497 dan tingkat signifikansi $t_{\text {hitung }}$ perencanaan audit sebesar 0,000 lebih kecil dari pada $\alpha=0,05$ yang memiliki arti bahwa perencanaan audit berpengaruh positif dan signifikan pada kualitas audit.

Demikian halnya dengan kompetensi auditor (b2) bernilai positif sebesar 0,462 dan tingkat signifikansi $t_{\text {hitung }}$ kompetensi auditor sebesar 0,003 lebih kecil dari pada $\alpha=0,05$ yang memiliki arti bahwa kompetensi auditor berpengaruh positif dan signifikan pada kualitas audit. Dengan demikian auditor Perwakilan BPKP Provinsi Bali tidak dapat mengabaikan perencanaan audit yang baik sebelum melakukan penugasan audit di lapangan dan auditor Perwakilan BPKP 
Provinsi Bali harus mempunyai pengetahuan, keterampilan, dan kompetensi lainnya yang diperlukan untuk melaksanakan tanggung jawabnya sebagai salah satu wujud pengendalian mutu kualitas audit.

Implikasi hasil penelitian yaitu perencanaan audit merupakan tahap penting bagi auditor dalam setiap hendak melakukan audit baik dalam audit keuangan, audit kinerja maupun audit tujuan tertentu. Rencana audit dimaksudkan untuk menjamin bahwa tujuan audit tercapai secara berkualitas, efisien dan efektif. Dengan adanya contoh kasus yang terjadi pada Perwakilan BPKP Provinsi Bali, dimana terdapat hasil audit yang dipertanyakan hasilnya oleh stakeholders (penasehat hukum dan tersangka) saat persidangan, karena hasil audit BPKP berbeda dengan hasil audit yang dilakukan oleh Badan Pemeriksa Keuangan, maka auditor perwakilan BPKP Bali tidak dapat mengabaikan perencanaan audit yang baik sebelum melakukan penugasan audit di lapangan. Hal tersebut dilakukan sebagai salah satu prosedur penjaminan mutu kualitas audit Perwakilan BPKP provinsi Bali. Auditor Perwakilan BPKP Provinsi Bali harus menjaga kualitas audit dengan melakukan perencanaan audit sesuai standar yang telah ditetapkan oleh BPKP.

Standar Audit Intern Pemerintah Indonesia (2014) menetapkan Standar Audit Intern Pemerintah Indonesia untuk menjaga kualitas audit yang dilakukan oleh Aparat Pengawasan Intern Pemerintah (APIP). Hasil audit penghitungan kerugian keuangan negara atas kasus tindak pidana korupsi pada Institit Hindu Darma Negeri (IHDN) Denpasar tahun 2012, dipertanyakan oleh penasehat hukum dan tersangka saat persidangan dan dinilai bersifat tendensius dalam 
memberikan keterangan sehingga diragukan kualitas audit dan kompetensi auditornya (Doso Sukendro, 2015). Dengan adanya fakta di persidangan tersebut, Auditor perwakilan BPKP Bali harus mempunyai pengetahuan, keterampilan, dan kompetensi lainnya yang diperlukan untuk melaksanakan tanggung jawabnya sebagai salah satu wujud pengendalian mutu kualitas audit. Auditor harus menjaga dan terus mengembangkan kompetensi auditornya sesuai dengan pedoman yang telah ditetapkan oleh BPKP.

\section{SIMPULAN}

Penelitian ini bertujuan untuk menganalisis pengaruh perencanaan audit dan kompetensi auditor pada kualitas audit di Perwakilan BPKP Provinsi Bali. Berdasarkan hasil pengujian regresi linier berganda terhadap data olah kuesioner dan pembahasan sebelumnya, maka dapat ditarik kesimpulan bahwa perencanaan audit berpengaruh positif pada kualitas audit di Perwakilan BPKP Provinsi Bali dan Kompeteni auditor berpengaruh positif pada kualitas audit di Perwakilan BPKP Provinsi Bali.

Berdasarkan simpulan dalam penelitian ini, maka saran untuk dapat menjadi pertimbangan bagi Auditor Perwakilan BPKP Provinsi Bali yaitu sebaiknya Auditor Perwakilan BPKP Provinsi Bali dapat menjaga kualitas audit dengan melakukan perencanaan audit sesuai standar yang telah ditetapkan oleh BPKP. Kemudian melakukan reviu atas ketepatan tujuan, sasaran, metodologi, waktu, dan biaya audit atas rencana dan realisasi yang dilakukan selama penugasan audit dari perencanaan hingga pelaporan sehingga dapat diketahui 
bahwa penugasan audit yang dilakukan tercapai secara berkualitas, ekonomis, efisien dan efektif.

Auditor Perwakilan BPKP Provinsi Bali juga disarankan agar secara rutin melakukan rotasi pegawai antar bidang, dengan tujuan untuk meningkatkan kompetensi audit dan menjaga independensi auditor serta memperluas pengetahuan, maupun melakukan reviu silang kertas kerja audit antar bidang pengawasan untuk menjamin kualitas kertas kerja yang menjadi dasar kualitas hasil audit.

Berdasarkan hasil uji regresi linier berganda diketahui bahwa nilai Adjusted $\mathrm{R}^{2}$ sebesar $71,5 \%$, yang berarti $71,5 \%$ kualitas audit dipengaruhi oleh variabel perencanaan audit dan kompetensi auditor sehingga masih terdapat $28.5 \%$ variabel lain yang berpengaruh terhadap kualitas audit yang dapat dilakukan penelitian lebih lanjut seperti independensi, lamanya waktu/proses audit, integritas, motivasi kerja, maupun etika auditor.

\section{REFERENSI}

Ardiansyah, Daeng Ahmad. 2014. Analisis Hubungan Antara Keahlian, Independensi, dan Etika dengan Kualitas Audit. Skripsi Sarjana Sains Terapan Jurusan Akuntansi pada Sekolah Tinggi Akuntansi Negara.

Asosiasi Auditor Intern Pemerintah Indonesia (AAIPI). 2014. Standar Audit Intern Pemerintah Indonesia. Jakarta: AAIPI.

Doso Sukendro. 2015. Laporan Pemberian Keterangan Ahli pada Perkara Dugaan Tindak Pidana Korupsi Pengadaan Barang dan Jasa Tahun 2011 pada IHDN Denpasar. Denpasar: BPKP.

Hakim, Fandya R. 2011. Pengaruh Independensi dan Kompetesi Terhadap Kualitas Hasil Audit, Studi Kasus Pada Badan Pengawasan Keuangan dan Pembangunan Jawa Timur. Skripsi Sarjana Sains Terapan Jurusan Akuntansi pada Sekolah Tinggi Akuntansi Negara. 
Jafar, T. Azmun. 2016. Gugat Hasil Produk Audit BPKP Terkait Dugaan Korupsi Bhakti Praja. http://www.jelajahriau.com/berita2903-T-Azmun-JafarGugat-Hasil-Produk-Audit-BPKP-Terkait-Dugaan-Korupsi-BhaktiPraja.html. Diakses 8 November 2017.

Keputusan Kepala Badan Pengawasan Keuangan dan Pembangunan Nomor KEP1446/K/SU/2008 Tahun 2008. Aturan Perilaku Pegawai BPKP. 23 Desember 2008. Jakarta.

Kurniawan Rosadhy, Farid. 2010. Pengaruh Perencanaan dan Tekanan Anggaran Waktu (Time Budget Pressure) terhadap Kualitas Hasil Pemeriksaan Laporan Keuangan Pemerintah Daerah (Studi pada BPK-RI Perwakilan Jawa Tengah). E-library Brawijaya University. http://elibrary.ub.ac.id/ handle/123456789/32884. Diakses 12 November 2017.

Najib, Ayu D. R. 2013. Pengaruh Keahlian, Indeppendensi dan Etika terhadap Kualitas Audit (Studi pada Auditor Pemerintah di BPKP Perwakilan Provinsi Sulawesi Selatan): Skripsi Sarjana Jurusan Akuntansi pada Fakultas Ekonomi dan Bisnis Universitas Hasanuddin, Makasar.

Peraturan Menteri Negara Pemberdayaan Aparatur Negara Nomor PER/05/M.PAN/03/2008. Standar Audit Aparat Pengawasan Intern Pemerintah. 31 Maret 2008. Jakarta.

Pusat Pendidikan dan Pelatihan Pengawasan BPKP. 2007. Kendali Mutu: Diklat Penjenjengan Auditor Pengendali Mutu. Jakarta. BPKP.

Sugiono. 2013. Metode Penelitian Bisnis (Pendekatan Kualitatif, Kuantitatif dan R\&D). Cetakan ke-17. Bandung: Penerbit Alfabeta.

2014. Statistika Untuk Penelitian. Cetakan ke-24. Bandung: Penerbit Alfabeta.

Uswatun Hasanah. 2013. Pengaruh Perencanaan Audit dan Pelatihan Teknis Terhadap Kualitas Audit (Studi pada Auditor Pemerintah di Inspektorat Kabupaten Jepara, Jawa Tengah). Skripsi Sarjana Jurusan Akuntasi pada Fakultas Ekonomi dan Bisnis Universitas Brawijaya, Malang.

Ussahawanitchakit, Phapruke. 2012. Effects of Audit Planning on Audit Quality of Certified Public Accountants (CPAs) in Thailand. Journal of Academy of Bussiness and Economics, 12 (3), hal. 85-98.

Zulfadli Abidi, Nadirsyah, dan Heru Fahlevi. 2016. Pengaruh Tingkat Pendidikan, Pelatihan Teknis, dan Perencanaan Penugasan Audit Terhadap Kualitas Hasil Audit pada Organisasi Sektor Publik (Studi pada Inspektorat Aceh). E-Jurnal Akuntansi Universitas Syiah Kuala, Banda Aceh, 5 (1), hal.53-67. 